\title{
Hydrotechnický výzkum kapacity sektorového uzávěru
}

MARTIN KRÁLÍK, JAN HLOM

Klíčová slova: povodňový průtok - hydraulický model - měrná křivka

\section{SOUHRN}

Příspěvek se zabývá hydraulickým a statickým posouzením sektorového uzávěru v Děčíně a v Českém Krumlově na základě vyhodnocení experimentálních měření provedených na fyzikálním hydraulickém modelu ve vodohospodár̆ské laboratoři Fakulty stavební ČVUT v Praze. Hydrotechnický výzkum popisuje měření hladin, průtoků a tlaků na obtékané ploše. Na modelu bylo vyhodnoceno mnoho typů technických možností úprav přelivu. Kapacita přelivu je ovlivňována manipulacemi s pohyblivými uzávěry. Klasické hydraulické výpočty nejsou dostatečně přesné vzhledem k velikosti a významnosti celého vodního díla. Z tohoto důvodu bylo přistoupeno k otestování zjednodušených teoretických hydraulických výpočtů pomocí fyzikálního hydraulického modelu.

\section{ÚVOD}

Hydrostatický sektor je typ jezové konstrukce, jehož pohyb se ovládá propojením tlačné komory s horní nebo dolní vodou. Spodní stavba jezu je navržena tak, aby se hradicí těleso zvedalo přetlakem vody vyvozeným při propojení prostoru horní vody s tlačnou komorou a sklápělo se při jejím propojení s dolní vodou. Hlavní výhodou hydrostatického sektoru je úspora pohybovacích mechanizmů, protože pohyb hradicího tělesa je zajištěn spojením přes trojcestný ventil rưznými polohami horní nebo dolní vody. Tlačná komora je tedy umístěna ve spodní stavbě jezu a podstatně se ušetří na výšce piliřur, což se príznivě projeví i při začlenění jezu do rámce krajiny. Rozhodujícími podmínkami pro správnou funkci je vytvoření dostatečného rozdílu hladin horní a dolní vody ve všech polohách hradicího uzávěru. Dále je potřeba zajistit podmínky pro zdvih při udržování stálého vzdutí a udržet hradicí uzávěr v nejnižší poloze při stoupání průtoků. Zvláštní pozornost nutno věnovat vlivu dolní vody a tvaru spodní stavby na funkci uzávěru. K dokonalé funkci hydrostatického sektoru je nutné, aby jeho vnitřní prostor byl stále naplněn vodou, nebo aby vniklý vzduch byl z horní části plněného prostoru odváděn. Hydraulické charakteristiky jsou podobné jako u jezů se strojním pohybem. Budování hydrostatických jezů je možné i v místech s omezeným prostorem, nebot prostorové nároky na technologii jsou malé. Jsou to pouze kanálky se šoupaty pro propojení tlačné komory s horní a dolní vodou a jejich ovládání. Umístování jezů může být i do míst s mírně nepř́iznivými hydraulickými podmínkami, které je potřeba prověřit na hydraulickém modelu. Opodstatnění fyzikálního modelování je zásadní v okruhu otázek ohledně upřesnění hydraulických charakteristik nebo v nalezení popisu jednotlivých hydraulických jevů, které nelze popsat rovnicemi a vzorci základní hydrauliky.

\section{PLAVEBNÍ STUPEŇ DĚČÍN}

Plánovaný plavební stupeň Děčín v ř. km 737,12 Labe je situován v levostranném oblouku v bezprostrední blízkosti děčínského přístavu Loubí. Plánovaný plavební stupeň Děčín má velký význam v možnosti využití labsko-vltavské vodní cesty pro lodní nákladní dopravu. Labsko-vltavská vodní cesta spojuje Českou republiku s př́stavy $v$ Severním a Baltském moři. V současné době není v úseku od státní hranice ČR/SRN zajištěna splavnost s dostatečným ponorem po velkou část roku. Navrhovaný plavební stupeň společně s koncentračními stavbami pod plavebním stupněm by měly zajistit splavnost s ponorem 1,4 metru po 345 dní v roce a s ponorem 2,2 metru po 180 dní v roce.

Plavební stupeň Děčín se skládá z jezu, plavební komory, malé vodní elektrárny a biokoridoru. Jez je tvořen třemi jezovými poli, každé o šîrce 40 metrů. Jednotlivá pole jsou oddělena piliríi, každý o šírce 4 metry. Pole jsou hrazena hydrostatickými sektory, které při plném sklopení navazují na betonovou konstrukci jezu a společně tvoři Jamborův práh. Jamborův práh převyšuje dno řeky o 1,3 metru. V jezovém tělese se nachází komunikační a revizní štola. Betonová konstrukce je dělena príčnými dilatačními spárami na několik celků. Tlumení energie prepadající vody je řešeno pomocí bezvývarového řešení. Na konci Jamborova prahu se nacházejí rozrážeče, za nimi je zához z lomového kamene. Zához je tvořen ze dvou frakcí, v bezprostřední blízkosti jezu se nachází frakce tvaru krychle o straně cca 1 metr, dále od jezu je „jemnější frakce o průměrném zrnu 0,45 metru.

Plavební komora je situována u levého konvexního břehu, její pozice je určena tak, aby i přes dlouhé rejdy na vstupu a z výstupu komory dobře navazovala na plavební dráhu lodí v oblouku. Užitná délka komory je 200 metrů, komoru je možné rozdělit na horní (38 m) a dolní (140 m) provozní délky. Užitná šírka komory je 24 metrư. Komora je tvořena železobetonovou polorámovou konstrukcí. Plnění a prázdnění komory je zajištěno pomocí dlouhých obtokư. Horní vrata jsou hrazena spustným segmentem, střední a dolní vrata jsou vzpěrná.

Vzniklý spád je využíván malou vodní elektrárnou nacházející se u pravého břehu mezi biokoridorem a jezovými poli. Elektrickou energii vyrábí dvě Kaplanovy turbíny o celkovém výkonu 7,9 MW a celkové hltnosti $250 \mathrm{~m}^{3} . \mathrm{s}^{-1}$. Na pravém břehu se nachází biokoridor o šířce 30 metrů sloužící pro překonání jezu veškerou vodní faunou a dále také suchozemskými živočichy [1].

Hydrostatický jez na plavebním stupni Děčín je tvořen spodní pevnou betonovou konstrukcí s tlačnou komorou a pohyblivým ocelovým uzávěrem. $\checkmark$ prahu jezového tělesa se nachází tlačná komora, s jejíž pomocí jsou ovládány hydrostatické sektory (obr. 1). Jezový uzávěr je tvořen svařenou ocelovou konstrukcí o výšce 5,2 metru a délce 40 metrů. Voda je do tlačné komory přiváděna potrubím, které prochází pod celou jezovou konstrukcí revizní štolou. Ocelová konstrukce uzávěru je otočná okolo ložisek umístěných na povodní straně. Sektor je možné zaaretovat v horní a dolní poloze. 


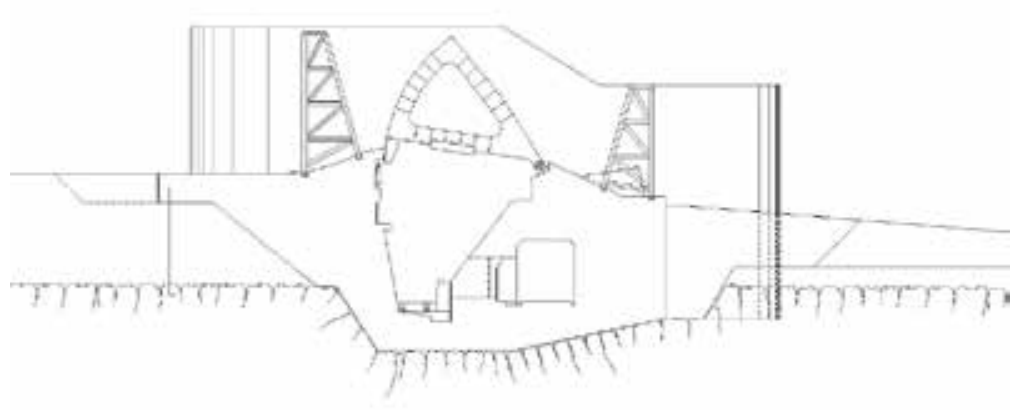

Obr. 1. Řez spodní stavby a hydrostatickým sektorem VD Děčín

Fig. 1. The cut of the substructure and the hydrostatic sector of the Děčín waterworks

\section{JEZ „JELENÍ LÁVKA“ - ČESKÝ KRUMLOV}

Jez "Jelení lávka“ je vzdouvacím stupněm na Vltavě v tradiční lokalitě centra Českého Krumlova s vysokou pohledovou expozicí. Původní jediný a základní účel jezu - hydroenergetické využití průtoku a spádu v pravobřežním objektu mlýna s návazným mlýnským odpadem mimo koryto Vltavy je dnes nutně spojen s účelem estetického vzdutí hladiny řeky podél městského centra.

V rámci protipovodňových opatření v Českém Krumlově byl v letech 2012 až 2013 rekonstruován jez "Jelení lávka“. Při této rekonstrukci byl pưvodní pevný jez nahrazen pohyblivým jezem hrazeným hydrostatickým sektorem. Rekonstrukce pevného jezu na pohyblivý byla provedena s ohledem na zlepšení průchodu povodní historickým centrem města.

Půdorysně šikmý jez vưči ose toku, zahrnující pevné a sklopné pole, zahrnuje širokou propust u levého břehu. Propust zajištuje smíšenou funkci koridoru sportovní či rekreační plavby a rybího přechodu přes spádový stupeň. U pravého břehu je vytvořen oddělením od řečiště nornou stěnou s lávkou prítokový kanál k objektu mlýna. Tento kanál přivádí vodu do dvou kašen vertikálních turbín, oddělených vzájemně užší jalovou propustí s osazeným vodním kolem, odtok od turbín je realizován odpadním kanálem mimo ríční koryto. Odkalení prítokového kanálu je zajištěno další jalovou propustí, hrazenou zdvižným stavidlem v prodloužené ose jezu.

Vodní dílo je tvořeno pohyblivým jezem, plavební propustí se současnou funkcí rybího přechodu při levém břehu a vtokovým zálivem - př́tokovým kanálem k MVE, umístěné pod budovou mlýna, na pravém břehu.

V úseku 40 m od pravobřežního pilíre je jez řešen jako sklápěcí pohyblivé pole s osazením ocelového hydrostatického sektoru s dřevěným opláštěním viditelné přelivné plochy. Zbytek délky jezu po levobřežní propust se zalomením osy koruny je řešen jako pole pevného jezu s vnitřní prístupovou chodbou k levému okraji pole sektoru. $V$ běžném provozu bude sektorový uzávěr trvale zaaretován v horní poloze z pravé strany. Po nástupu povodňových průtoků ve stanovený okamžik bude ručně uzávěr odaretován a sklopen. Po konci povodně bude uzávěr $v$ určený okamžik opět vztyčen a zaaretován. Tvar hydrostatického sektoru je atypický, prodloužený v přelivné ploše pevného jezu pohyblivé pole tak odpovídá vizuální podobě spodní stavby pevného jezu (obr. 2).

Pohyb hydrostatického sektoru nahoru a dolů je řešen trubním propojením jeho tlačné komory s horní či dolní vodou. Pro některé přechodové stavy je plnění i prázdnění tlačné komory podpořeno čerpáním. Armaturní komora je umístěna $v$ pravém dutém piliŕi jezu. Levé zavázání sektoru zahrnuje pouze horní aretaci uzávěru pro účel revize tlačné komory při jejím vyčerpání. Přístup k aretaci je možný chodbou od šachty v pilíri propusti v konstrukci pevného jezu.

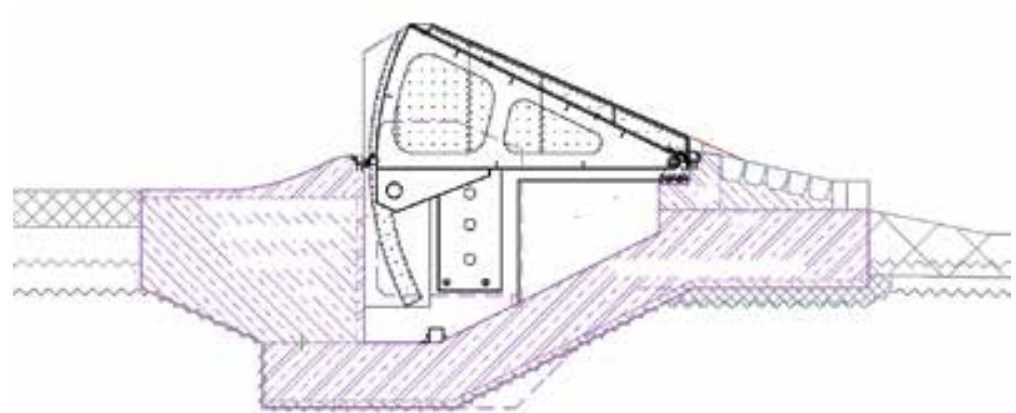

Obr. 2. Řez spodni stavbou a hydrostatickým sektorem VD Český Krumlov Fig. 2. The cut of the substructure and the hydrostatic sector of the Český Krumlov waterworks

Jezová propust u levého břehu má smíšenou funkci vodácké propusti a rybího přechodu. V šiřce propusti je vytvořena plavební snížená kyneta s větším preronem vody. Zdrhla v propusti, které zpomalují i čeří proud v propusti, zároveň vytváří mezilehlé tišiny jako útočiště ryb v pohybu proti proudu. Zdrhla jsou vytvořena z poměrně vysokých plastových polí kartáčů. Výška kartáčủ ve střední snížené plavební kynetě je $50 \mathrm{~cm}$, v přidružených bočních polích pak $30 \mathrm{~cm}$.

Na pravém břehu v břehové linii nadjezí, je před vtokem do mlýna instalována norná stěna s možností osazení hrubých česlí světlosti $30 \mathrm{~cm}$. Norná stěna je vytvořena jako srubová konstrukce s horní lávkou a jednoduchým dřevěným zábradlím. Po lávce je umožněn přístup obsluhy $k$ armaturní komoře, v konstrukci v chráničkách pod mostovkou vedou i kabely NN prípojky k jezu. Za stěnou navázanou na pravobřežní piliř jezu s armaturní komorou je prostor přiváděcího kanálu ke kašnám dvou turbín, pod objektem mlýna s navazujícím derivačním odpadem, zaústěným dále do Vltavy [2].

\section{POPIS KONSTRUKCE HYDROSTATICKÉHO UZÁVĚRU}

Hydrostatický pohyblivý jez je tvořen pevnou spodní stavbu s tlačnou komorou a ocelovým pohyblivým uzávěrem. Tvar spodní stavby odpovídá požadavku osazeného typu pohyblivého jezového uzávěru - hydrostatického sektoru. Tlačná komora jezu je spojena vodotěsnými dveřmi s armaturní komorou a s prístupovou chodbou pod pevnou částí jezu od dělícího piliře propusti. $\checkmark$ tlačné komoře jsou na povodním prahu zakotvena ložiska sektoru. V ozubech spodní stavby jsou dále zakotveny profily prahových těsnění sektoru. Část spodní stavby jezu tvoří Jamborův práh. V rámci prahu jsou do spodní stavby zakotveny patky slupic provizorního hrazení jezu.

\section{KAPACITA JEZU}

Sektor je možné zaaretovat v horní a dolní poloze. Za běžných průtoků nebude s hydrostatickým sektorovým uzávěrem, zaaretovaným v horní poloze, nijak manipulováno. Výjimkou mohou být krátkodobé kontrolní funkční zkoušky a revizní prohlídky. Za povodně bude hydrostatický sektorový uzávěr sklopen a zaaretován v dolní poloze. 


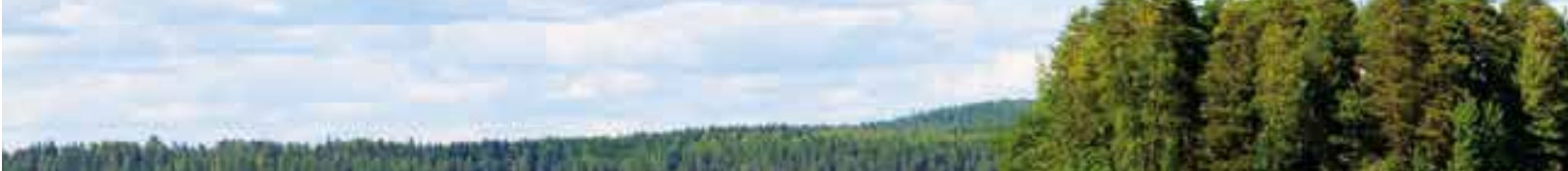




(n)

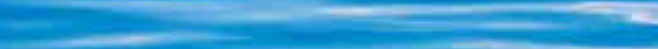

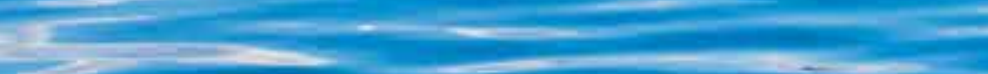

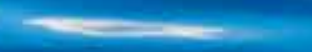


Měrná křivka jednotlivých částí jezu i celek byla počítána na základě hydraulického výpočtu pro přepad vody:

$$
Q=\sigma_{z} m b_{0} \sqrt{2 g} h_{0}^{3 / 2}
$$

kde $Q$ je průtok $\left[\mathrm{m}^{3} \cdot \mathrm{s}^{-1}\right]$,

$\sigma_{z} \quad$ součinitel zatopení,

$m$ součinitel přepadu,

b. účinná šířka přelivu [m],

$g$ tíhové zrychlení $\left[\mathrm{m} \cdot \mathrm{s}^{-2}\right]$,

$h_{0} \quad$ přepadová výška [m].

Měrné křivky jednotlivých objektů byly počitány pro mnoho poloh hydrostatického sektoru. Nutno poznamenat, že přesnost výpočtů je dána geometrií, složitostí stavebních konstrukcí a velikostí zatopení dolní vodou, která má přímý vliv na kapacitu objektů. Při hydraulických výpočtech bylo nutno zohlednit tvary přelivných ploch jednotlivých částí jezu součinitelem přepadu a dispozičního uspořádání stavebních konstrukcí odpovídajícími součiniteli bočního zúžení. Zohlednit všechny ukazatele, které ovlivňují kapacitu přelivu, při různých hladinách vody ve zdrži, je prakticky nepostihnutelné a oddělit od sebe součinitele pro jednotlivé části jezu (včetně přelévaných pilî̌ru) je nemožné.

\section{HYDROTECHNICKÝ MODELOVÝ VÝZKUM}

Hydraulické jevy, proudění vody a jeho hydraulické charakteristiky je možno zkoumat na postaveném vodním díle, nicméně z objektivních príčin je tento výzkum značně ztížen, proto se často přistupuje ke zkoumání na zmenšeném modelu vodního díla v laboratorních podmínkách. Počáteční, okrajové a limitující podmínky jsou dány rozměrovou, silovou a hmotnostní analýzou, které vychází z podmínek zkoumání jevů na modelu pomocí Froudova zákona mechanické podobnosti. Pokud existuje alespoň částečná rozměrová podobnost, je možno použít pro hydraulické výpočty analogii z předchozích výzkumů. Přepočet jednotlivých charakteristik z původního modelu na skutečné vodní dílo Ize provést pomocí vzorců:

- měrítko délek $M_{\mu}$

- měrítko rychlostí $\quad M_{v}=M_{1}^{1 / 2}$

- měŕítko průtoků $M_{0}=M_{1}^{5 / 2}$,

- měrítko sil $\quad M_{F}=M_{1}^{3}$.

Měř́tko modelu jezu s hydrostatickým sektorem bylo určeno na základě mezních podmínek modelové podobnosti, možnostech laboratoře, konstrukčních možnostech a podmínek reprezentativnosti výzkumu. Zvolená měřitka pro model jezu v Děčíně byla podle vzorců stanovena takto: délek $M_{1}=1: 20$, rychlostí je $M_{v}=1: 4,47$, průtoků je $M_{0}=1: 1789$ a sil je $M_{F}=1: 8000$. Zvolená měŕítka pro model Český Krumlov byla podle vzorců stanovena takto: délek $M_{1}=1: 16$, rychlostí je $M_{v}=1: 4$, průtoků je $M_{\mathrm{O}}=1: 1024$ a sil je $M_{\mathrm{F}}=1: 4096$.

Voda byla k modelu hydrostatického sektoru přiváděna rozváděcím potrubím v laboratoři, průtok byl měřen pomocí magneticko-indukčního průtokoměru, voda byla uklidněna v uklidňovací nádrži. Voda z modelu byla odvedena sběrnou nádrží do podzemních prostor vodohospodářské laboratoře, kde je umístěna centrální akumulace vody.

Cílem modelového výzkumu bylo ověrit a zpresnit hydraulické výpočty jezu s hydrostatickým sektorem. Kapacitu jezu ovlivňuje tvar přelivné plochy, drsnost prélivné plochy, pilíre mezi jednotlivými poli, předpolí jezu a dolní voda $\checkmark$ korytě pod jezem. Všechny tyto detaily bylo potřeba zohlednit při fyzikálním modelování, aby výsledky byly co nejvěrohodnější.

\section{VÝSLEDKY EXPERIMENTU゚}

Výsledky pokusư všech měření jsou zaznamenány pomocí měrné křivky hydrostatického sektoru a pomocí grafických závislostí sil působících na hydrostatický sektor (nejsou součástí tohoto článku).

Pro úplnost měření byly změřeny a vyhodnoceny konzumční křivky hydrostatického sektoru v mezipolohách mezi úplným vztyčením a úplným sklopením. Při úplném sklopení hydrostatického sektoru v Českém Krumlově byl do výpočtu zahrnut součinitel zatopení dolní vodou. Součinitel zatopení dolní vodou byl uvažován pro polohy hladin dolní vody nad přelivnou hranou sklopeného hydrostatického sektoru. Na hydraulickém modelu byla dolní hladina nastavována podle konzumční křivky dolní vody.

Z obr. 3 konzumčních křivek VD Děčín je patrný rozdíl kapacit mezi jednotlivými polohami hydrostatického sektoru. Kapacita prèlivu je velkou měrou závislá na geometrickém tvaru, proto se s různými polohami hydrostatického sektoru mění. Na obr. 4 konzumčních křivek jezu v Českém Krumlově Ize pozorovat výrazný rozdíl v kapacitě jezu vztyčeného hydrostatického sektoru ve srovnání se sklopeným uzávěrem. Součinitel přelivu je také $v$ tomto případě výrazně ovlivňován nátokovými podmínkami v nadjezí a dolní vodou pod jezem.
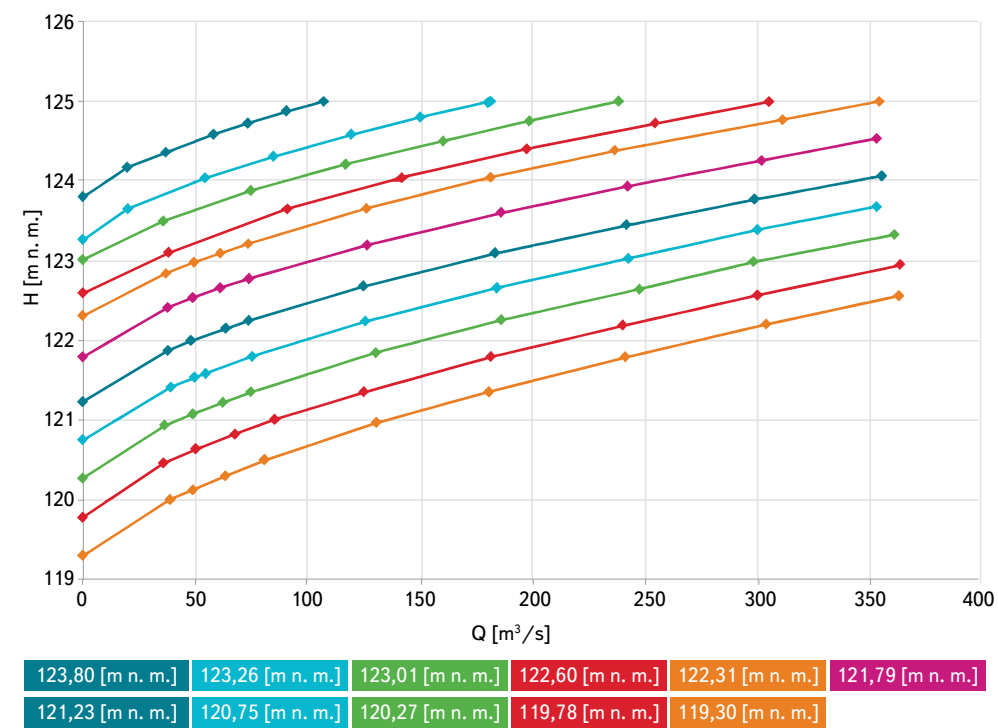

Obr. 3. Měrná křivka jezu Děčín

Fig. 3. The specific curve of the Děčín weir

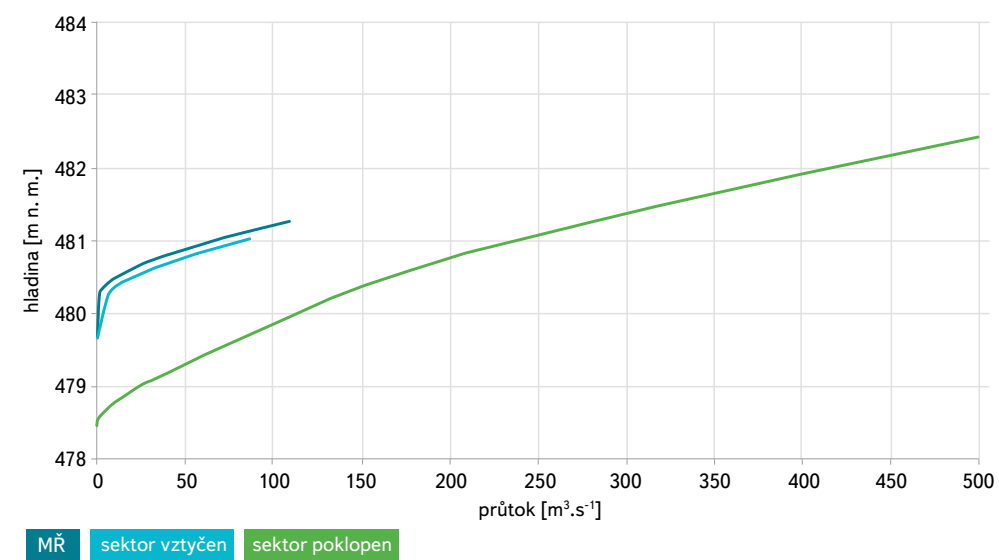

Obr. 4. Měrná křivka jezu „Jelení lávka” - výpočet Králík × manipulační řád Fig. 4. Specific curve weir "Jelení lávka" - calculation of Králík and handling regulations 
V rámci všech měření přepadových výšek přes hydrostatický sektor byly také měřeny polohy hladiny $v$ místě druhé vzájemné hloubky a dále poloha hladiny dolní vody. Při všech pokusech se pod sektorem nalézal prostý vodní skok. Veškerá kinetická energie byla utlumena v přilehlém prostoru, kde se očekává tlumení kinetické energie podle projektu.

Na hydrostatický sektor působí vnější síly od vlastní tíhy, statického a dynamického působení vody a třecí síly v ložiscích a těsněních. Model hydrostatického sektoru byl vyroben z plastů a těsnění potřebné pro správnou funkci z pryže, která při stejném zatížení vodou může vykazovat různé tření mezi konstrukcí piliřru a sektorem, a tím znehodnotit měření vnějších sil. Pro měření reakc sil byly pokusy opakovány třikrát po sobě a výsledky vykazovaly naprostou shodu, což je důkaz pro korektnost naměřených údajů a nezávislost postupu na možných diferencích třecích sil. Vyhodnocení sil je možno použít při výpočtu zatížení na hydrostatický sektor a pro návrh manipulace pomocí vztlakové síly v tlačné komoře.

\section{ZÁVĚR}

Určení měrné křivky pohyblivého jezu s hydrostatickým sektorem se opírá rovněž o výsledky předchozích výzkumů, které ale nepostihovaly konkrétní tvar prelivné plochy a podmínek proudění vody před hydrostatickým sektorem jezu. Proto je součinitel prepadu odlišný od původního výpočtu. Rozdíl původního součinitele přepadu zjištěného z literatury [3] ve srovnání se součinitelem vypočteným z naměřených hodnot průtoku a přepadové výšky je 4 \% při zdviženém sektoru a 12,5\% při sklopeném sektoru.

Hydraulické fyzikální modelování má své opodstatnění při řešení složitých úloh návrhu a posouzení hydrotechnických děl. Při posouzení nově navrženého i stávajícího stavu jezu a navazujících objektů byl použit hydraulický model, který věrně popisuje proudění na jednotlivých objektech. Výsledky řešení stávajícího stavu byly znázorněny ve formě grafického zpracování měrných křivek a křivek vnějších sil působících na konstrukci hydrostatického sektoru. Výsledky těchto měření mohou být použity pro posouzení a optimalizaci všech dílčích částí jezu. Znalosti získané v modelovém výzkumu, nejen významných vodních děl, jsou velmi ceněné a $v$ celkovém pojetí jsou získány za malou cenu z ceny projektu, či za zlomek ceny z výstavby plánovaného vodního díla [4].

\section{Poděkování}

Tento článek vznikl za podpory grantu SGS19/046/OHK1/1T/11 Kombinovaný výzkum proudèní vody na hydrotechnických stavbách.

\section{Literatura}

[1] FOŠUMPAUR, P. a kol. Fyzikální hydraulický modelový výzkum plavebni komory Děčín. výzkumná zpráva. Praha, 2016

[2] KRÁLíK, M. Hydrotechnický výzkum sektorového uzávěru. Vodní hospodářství, 2017.

[3] HAVLÍK, V. a MAREŠOVÁ, I. Hydraulika (př́klady). skripta. Praha: ČVUT, 1990.

[4] ČÁBELKA, J. a GABRIEL, P. Matematickéa fyzikálnímodelovánív hydrotechnice. Praha: Academia، 1987.

\section{Autoři}

Ing. Martin Králík, Ph.D.'

冈martin.kralik@fsv.cvut.cz

Ing. Jan Hlom ${ }^{1,2}$

凶jan.hlom@vuv.cz

'Katedra hydrotechniky, Fakulta stavební ČVUT v Praze

${ }^{2}$ Výzkumný ústav vodohospodářský T. G. Masaryka, v. v. i.

Příspěvek prošel lektorským řizením.

\section{HYDROTECHNICAL RESEARCH OF A SECTOR GATE}

\section{KRALIK, M.'; HLOM, J.,2}

'Department of Hydrotechnics, Faculty of Civil Engineering CTU in Prague ${ }^{2}$ TGM Water Research Institute, p.r.i.

Keywords: flood discharge - hydraulic model - consumption curve

The article deals with the hydraulic and structural assessment of a sector gate in Děčín and Český Krumlov based on the evaluation of experimental measurements performed on a physical hydraulic model In the Water Management Laboratory of the Faculty of Civil Engineering, CTU in Prague. The hydrotechnical investigation describes the measurement of levels, discharges and pressures in the spillway. Many types of technical options of the spillway modifications were evaluated on the model. The capacity of the spillway structure is influenced by the operation of the gates. Standard hydraulic formulas cannot be regarded as accurate enough considering the size and importance of the entire hydraulic structure. For the reasons mentioned above the simplified theoretical calculations were validated on the physical hydraulic model. 